\title{
Identifying the top issues of marine invasive alien species in Europe
}

\author{
Henn Ojaveer ${ }^{1}$, Bella S. Galil ${ }^{2}$, Stephan Gollasch ${ }^{3}$, Agnese Marchini $^{4}$, Dan Minchin ${ }^{5,6}$, \\ Anna Occhipinti-Ambrogi ${ }^{4}$ and Sergej Olenin ${ }^{6}$ \\ ${ }^{1}$ Estonian Marine Institute, University of Tartu, Pärnu, Estonia \\ ${ }^{2}$ National Institute of Oceanography, Haifa, Israel \\ ${ }^{3}$ GoConsult, Hamburg, Germany \\ ${ }^{4}$ Department of Earth and Environmental Sciences, University of Pavia, Pavia, Italy \\ ${ }^{5}$ Marine Organism Investigations, 3 Marina Village, Ballina, Killaloe, Co Clare, Ireland \\ ${ }^{6}$ Marine Research and Technology Center, Klaipeda University, Klaipeda, Lithuania \\ E-mail:henn.ojaveer@ut.ee(HO),bella@ocean.org.il(BSG),sgollasch@aol.com(SG),agnese.marchini@unipv.it(AM), \\ moiireland@yahoo.ie(DM),occhipin@unipv.it(AOA),sergej@corpi.ku.lt(SO) \\ * Corresponding author
}

Received: 29 April 2014 / Accepted: 28 May 2014 / Published online: 5 June 2014

Handling editor: Vadim Panov

\begin{abstract}
Stemming from a recent freshwater invasives conference, Caffrey et al. (2014) identified 'the top 20 issues' that relate to invasive alien species (IAS) management in Europe. With a view to complement and balance the issues highlighted in their account, we offer six important additions that relate to the marine environment. These are: preventive measures, concerns of loss of taxonomic expertise and species identity, gaps in the knowledge of certain taxa and regions, inconsistencies of terminology, need for validation of data and the importance of concentrating on pathways, and their vectors, and levels of certainty associated with these routes.
\end{abstract}

Key words: non-indigenous species, information needs, standardization, management, international cooperation

\section{Introduction}

Invasions of non-indigenous species (NIS) are acknowledged as one of the major threats to natural environments - terrestrial, freshwater and marine - having ecological, economic and social consequences. A recently published Proposal for a Regulation of the European Parliament and of the Council on the prevention and management of the introduction and spread of invasive alien species (European Commission 2013) states that "...The impact of IAS on biodiversity is significant ... one of the major, and growing, causes of biodiversity loss and species extinction...". The EU Biodiversity Strategy (European Commission 2011) aims that "...by 2020, Invasive Alien Species (IAS) and their pathways are identified and prioritised, priority species are controlled or eradicated, and pathways are managed to prevent the introduction and establishment of new IAS...". Galil et al. (2014) recorded 879 multicellular NIS in European Seas, with a doubling of the number of
NIS records between 1970 and 2013 within some regions. Stemming from a recent freshwater invasives conference, Caffrey et al. (2014) identified 'the top 20 issues that relate to IAS management in Europe". We agree and support all the issues proposed, and would like to contribute to this important initiative by adding six important topics that relate to the marine environment.

\section{Results}

1. Regulatory framework to prevent introduction of IAS

When dealing with the international agreements and measures to prevent introduction of marine IAS, the following documents are fundamental to the conservation and management of the marine environment: the International Convention for the Control and Management of Ships' Ballast Water and Sediments (IMO 2004), ICES Code of Practice on the Introductions and Transfers of Marine Organisms (ICES 2005), Alien Species in 
Aquaculture - IUCN considerations for responsible use (Hewitt et al. 2006), EC Regulation on concerning use of alien and locally absent species in aquaculture (European Commission 2007) and EC Marine Strategy Framework Directive (European Commission 2008). These, together with the Proposal for a Regulation of the European Parliament and of the Council on the prevention and management of the introduction and spread of invasive alien species (European Commission 2013) provide the legislative framework and identify some surveillance and management needs for NIS in the marine environment, by covering both deliberate releases as well as accidental introductions. These documents indicate the level, scale and scope of joint efforts required to deal with bioinvasions in the marine environment at an international scale.

\section{Reliable NIS identifications and loss of taxonomic expertise}

Underpinning the efforts for the prevention and management of the introduction and spread of IAS, be it terrestrial or aquatic, is the assumption that we are able to recognize the NIS from the indigenous. Yet, in the marine realm there is a lack/uncertainty of information for many of the small-sized phyla due to limited research effort and continuing erosion of taxonomic expertise (Terlizzi et al. 2003). For instance, a recent study of diatoms and dinoflagellates reported as NIS in European Seas found dubious identifications, and that synonyms were included as separate species (Gómez 2008). Misidentification of NIS as indigenous and vice versa is not uncommon: the Atlantic bryozoan Zoobotryon verticillatum and the Pacific isopod Paranthura japonica were assumed to be native to the Mediterranean, whereas the Atlantic comb jelly Mnemiopsis leidyi was misidentified in the North Sea as a morphologically similar native species and some native macroalgae and hydroids had been identified as NIS (Faasse and Bayha 2006; Schuchert 2010; Tsiamis et al. 2010; Lavesque et al. 2013; Galil and Gevili 2014; Marchini et al. 2014).

\section{Data-gaps impede comprehensive assessments}

Arising from issue 2, the poor coverage of data and information on several taxonomic groups, some of which include disease agents and pathogens (Drake et al. 2007), should be considered as major gaps in the knowledge base when undertaking marine NIS assessments (Roy et al. 2014). The unicellular NIS are also underreported, though it is well established that anthropogenic dispersal and redistribution of propagules in ballast water and sediments, biofouling and shellfish transplantation, facilitate their range expansions (Hudson and Hill 1991; Hülsmann and Galil 2002; Minchin and Gollasch 2003; David et al. 2007). Gaps are evident also in coverage of different habitats and geographical regions: for example, half as many marine NIS have been recorded from Syria as from Lebanon, and a third as reported from the Mediterranean coast of Turkey (Galil et al. 2014). Compared to the terrestrial realm, environmental impacts of marine NIS are not as well studied (Pyšek and Richardson 2010) and therefore fragmentally documented (e.g. Ruiz et al. 1999). These deficiencies as a result hamper comprehensive environmental assessments of marine NIS and deserve greater attention.

\section{Need for a unified and appropriate terminology}

There is a need for a unified, unambiguous and appropriate terminology, based on transparent, quantitative criteria, to describe the status of biological invasions (Occhipinti-Ambrogi and Galil 2004). Several high-level EU policy documents use ambiguous terminology (e.g. non-indigenous species vs. non-indigenous exotic species; non-indigenous species introduced by human activities), or introduce undefined and non quantitative criteria (e.g. significant negative effect and serious economic damage) (e.g. European Commission 2008, 2010, 2013). In order to avoid misinterpretations and enhance harmonization of efforts, the terminology should be inevitably standardized. The unified suggestion for the terminology for invasive biota (Blackburn et al. 2011) should be consulted and applied in the harmonizing process.

\section{Standardization of data and information systems}

In order to ensure comprehensive assessments, data and information systems should be scientifically validated and standardized (Ojaveer et al. 2014). An example is provided by the AquaNIS information system (http://www.corpi. ku.lt/databases/index.php/aquanis), dealing with aquatic NIS and cryptogenic introductions to marine, brackish and coastal freshwater environments of Europe and adjacent regions, which is designed to assemble, store and disseminate comprehensive data for both NIS and cryptogenic biota and aid in achieving management goals (Olenin et al. 2014). Also, the European Alien Species Information Network (EASIN; http://easin.jrc.ec.europa.eu/), 
developed by the European Commission to harmonize and integrate information, comprises at present several relevant existing European, regional and national databases (Katsanevakis et al. 2012).

\section{Management should focus on invasion pathways/ vectors and be regionally coordinated}

The main pathways/vectors for introduction of marine NIS to European Seas are shipping, aquaculture and canals with the Suez Canal likely to be 'responsible' for a third of the marine NIS in European Seas, and more than two thirds in the eastern Mediterranean Sea (Galil et al. 2014). However, secondary dispersal also takes place with currents, and unlike many inland water bodies, seas are connected. Therefore, the entire scope of 'issues' and 'recommendations' should be calibrated to take account of these realities. A unified EU strategic approach to marine biosecurity and 'rapid response' will be to little avail without the coordination and the cooperation of those nations within regional seas (e.g. Sambrook et al. 2014). When compared with terrestrial and freshwater bioinvasions, only a handful of eradications in the marine environment (e.g. Bax et al. 2002; Wotton et al. 2004; Galil 2002) will have suceeded. Therefore, invasion pathway/vectors management is key for success in dealing with NIS in the marine environment when developing NIS management strategies and converting these into legislative acts. Where possible, pre-border prevention measures should be taken into account (ICES 2005; David and Gollasch 2008). However, knowledge of the level of certainty ascribed to pathways and their vectors is also needed (Olenin et al. 2010). The scrupulous and rigorous monitoring of pathway/ vector introduction hubs and habitats/locales vulnerable to invasion (i.e. harbours and marinas as well as aquaculture sites) is of the outmost importance for management. Further, established NIS, as well as newly recorded ones, should be carefully monitored for outbreaks and blooms.

\section{Conclusions}

The six issues concerning marine IAS outlined above stem from discussions held among participants in several EU-funded projects (MarBEF, IMPASSE, ALARM, DAISIE and VECTORS), as well as among members of the Working Groups on Introductions and Transfers of Marine Organisms (WGITMO) and Ballast and Other Ship Vectors (WGBOSV) of the
International Council for the Exploration of the Sea (ICES). We suggest these topics deserve attention at national, regional and pan-European level. This will hopefully lead to a systematic and comprehensive assessment and management of IAS in Europe and through this ensure longterm sustainability and protection of the marine environment Latvian waters.

\section{Acknowledgements}

The authors thank the handling editor and two anonymous referees for their valuable comments. The research leading to these results has received funding from the European Community's Seventh Framework Program (FP7/2007-2013) under Grant Agreement no. 266445 for the Vectors Change in Oceans and Seas Marine Life, Impact on Economics Sectors (VECTORS). The authors are indebted to colleagues in EUfunded projects such as MarBEF, IMPASSE, ALARM and DAISIE, as well as members of ICES WGITMO and WGBOSV.

\section{References}

Bax N, Hayes K, Marshall A, Parry D, Thresher R (2002) Manmade marinas as sheltered islands for alien marine organisms: establishment and eradicationof an alien invasive marine species. In: Weitch CR, Clout MN (eds), Turning the tide: the eradication of invasive species. IUCN SSC Invasive Species Specialist Group. IUCN Gland, Swizterland and Cambridge, UK, pp 26-39

Blackburn TM, Pyšek P, Bacher S, Carlton JT, Duncan RP, Jarošík V, Wilson JRU, Richardson DM (2011) A proposed unified framework for biological invasions. Trends in Ecology\&Evolution 26(7): 334-339, http://dx.doi.org/10.1016/ j.tree.2011.03.023

Caffrey JM, Baars, J-R, Barbour JH, Boets P, Boon P, Davenport K, Dick JTA, Early J, Edsman L, Gallagher C, Gross J, Heinimaa P, Horrill C, Hudin S, Hulme PE, Hynes S, MacIsaac HJ, McLoone P, Millane M, Moen TL, Moore N, Newman J, O'Conchuir R, O'Farrell M, O’Flynn C, Oidtmann B, Renals T, Ricciardi A, Roy H, Shaw R, Weyl O, Williams F, Lucy FE (2014) Tackling Invasive Alien Species in Europe: the top 20 issues. Management of Biological Invasions 5: 1-20, http://dx.doi.org/10.3391/mbi.2014.5.1.01

David M, Gollasch S (2008) EU shipping in the dawn of managing the ballast water issue. Marine Pollution Bulletin 56: 1966-1972, http://dx.doi.org/10.1016/j.marpolbul.2008.09.027

David M, Gollasch S, Cabrini M, Perkovič M, Bošnjak D, Virgilio D (2007) Results from the First Ballast Water Sampling Study in the Mediterranean Sea - the Port of Koper Study. Marine Pollution Bulletin 54(1): 53-65, http://dx.doi.org/10.1016/j.marpolbul.2006.08.041

Drake LA, Doblin MA, Dobbs FC (2007) Potential microbial bioinvasions via ships' ballast water, sediment, and biofilm. Marine Pollution Bulletin 55(7-9): 333-341, http://dx.doi.org/ 10.1016/j.marpolbul.2006.11.007

European Commission (2007) Council regulation (EC) no. $708 / 2007$ of 11 June 2007 concerning use of alien and locally absent species in aquaculture. Official Journal of the European Communities no. L168: 1-17

European Commission (2008) Directive 2008/56/EC of the European Parliament and of the Council of 17 June 2008 establishing a framework for community action in the field of marine environmental policy (Marine Strategy Framework Directive). Official Journal of the European Communities no. L164: 19-40 
European Commission (2010) Decision on criteria and methodological standards on good environmental status of marine waters. Decision 2010/477/EU. Official Journal of the European Communities no. L 232: 14-24

European Commission (2011) Our life insurance, our natural capital: an EU biodiversity strategy to 2020 . Communication from the Commission of the European Parliament, the Council, the Economic and Social Committee and the Committee of the Regions COM (2011) 244, Brussels, Belgium, May 3, 2006, $17 \mathrm{pp}$

European Commission (2013) Proposal for a regulation of the European parliament and of the council on the prevention and management of the introduction and spread of invasive alien species COM (2013) 620 final, COD (2013) 0307, Brussels, Belgium, September 9, 2013, $36 \mathrm{pp}$

Faasse MA, Bayha KM (2006) The ctenophore Mnemiopsis leidyi A. Agassiz 1865 in coastal waters of the Netherlands: an unrecognized invasion? Aquatic Invasions 1: 270-277, http://dx.doi.org/10.3391/ai.2006.1.4.9

Galil BS (2002) Control and eradication of invasive aquatic invertebrates. In: Gherardi F, Corti C, Gualtieri M (eds), Biodiversity conservation and habitat management. The Encyclopedia of Life Support Systems, EOLSS Publishers; Oxford; UK/UNESCO, 1-14 pp

Galil BS, Gevili R (2014) Zoobotryon verticillatum (Delle Chiaje, 1822) (Bryozoa, Ctenostomatida, Vesiculariidae), a new occurrence in the Mediterranean coast of Israel. Marine Biodiversity Records 7: e17, http://dx.doi.org/10.1017/S1755267 214000086

Galil BS, Marchini A, Occhipinti-Ambrogi A, Minchin D, Narščius A, Ojaveer H, Olenin S (2014) International arrivals: widespread bioinvasions in European Seas. Ethology Ecology and Evolution 26: 152-171, http:/dx.doi.org/10.1080/ 03949370.2014 .897651

Gómez F (2008) Phytoplankton invasions: comments on the validity of categorising the non-indigenous dinoflagellates and diatoms in Eurpean seas. Marine Pollution Bulletin 56: 620-628, http://dx.doi.org/10.1016/j.marpolbul.2007.12.014

Hewitt CL, Campbell ML, Gollasch S (2006) Alien Species in Aquaculture. Considerations for responsible use. IUCN, Gland, Switzerland and Cambridge, UK. viii +32 pp

Hudson EB, Hill BJ (1991) Impact and spread of bonamiasis in the UK. Aquaculture 93(3): 279-285, http://dx.doi.org/10.10 16/0044-8486(91)90240-8

Hülsmann N, Galil BS (2002) Protists - a dominant component of the ballast-transported biota. In: Leppäkoski E, Gollasch S, Olenin $\mathrm{S}$ (eds), Invasive aquatic species in Europe: distribution, impacts and management. Kluwer, pp 20-26, http://dx.doi.org/10.1007/978-94-015-9956-6 3

ICES (2005) ICES code of practice on the introductions and transfers of marine organisms. ICES, $30 \mathrm{pp}$

IMO (2004) International convention for the control and management of ships' ballast water and sediments. IMO, $38 \mathrm{pp}$

Katsanevakis S, Bogucarskis K, Gatto F, Vandekerkhove J, Deriu I, Cardoso AC (2012) Building the European Alien Species Information Network (EASIN): a novel approach for the exploration of distributed alien species data. BioInvasions Records 1: 235-245, http://dx.doi.org/10.3391/bir.2012.1.4.01

Lavesque N, Sorbe J-C, Bachelet G, Gouillieux B, de Montaudouin Z, Bonifacio P, Blanchet H, Dubois S (2013) Recent discovery of Paranthura japonica Richardson, 1909 (Crustacea: Isopoda: Paranthuridae) in European marine waters (Arcachon Bay, Bay of Biscay). BioInvasion Records 2: 215-219, http://dx.doi.org/10.3391/bir.2013.2.3.07

Marchini A, Sorbe J-C, Torelli F, Lodola A, Occhipinti-Ambrogi A (2014) The non-indigenous Paranthura japonica Richardson, 1909 in the Mediterranean Sea: travelling with shellfish? Mediterranean Marine Science (in press), http://dx.doi.org/10.12681/mms. 779
Minchin D, Gollasch S (2003) Fouling and ships' hulls: how changing circumstances and spawning events may result in the spread of exotic species. Biofouling 19: 111-122, http://dx.doi.org/10.1080/0892701021000057891

Occhipinti-Ambrogi A, Galil BS (2004) A uniform terminology on bioinvasions: a chimera or an operative tool? Marine Pollution Bulletin 49: 688-694, http://dx.doi.org/10.1016/j.mar polbul.2004.08.011

Ojaveer H, Galil BS, Minchin D, Olenin S, Amorim A, CanningClode J, Chainho P, Copp GH, Gollasch S, Jelmert A, Lehtiniemi M, McKenzie C, Mikus J, Miossec J, OcchipintiAmbrogi A, Pećarević M, Pederson J, Quilez-Badia G, Wijsman JWM, Zenetos A (2014) Ten recommendations for advancing the assessment and management of nonindigenous species in marine ecosystems. Marine Policy 44: 160-165, http://dx.doi.org/10.1016/j.marpol.2013.08.019

Olenin S, Alemany F, Cardoso AC, Gollasch S, Goulletquer P, Lehtiniemi M, McCollin T, Minchin D, Miossec L, Occhipinti Ambrogi A, Ojaveer H, Jensen KR, Stankiewicz M, Wallentinus I, Aleksandrov B (2010) Marine Strategy Framework Directive - Task Group 2 Report. Nonindigenous species, Office for Official Publications of the European Communities, Luxembourg, EUR 24342 EN, ISBN 978-92-79-15655-7, ISSN 1018-5593

Olenin S, Narščius A, Minchin D, David M, Galil B, Gollasch S, Marchini A, Occhipinti-Ambrogi A, Ojaveer H, Zaiko A (2014) Making non-indigenous species information systems practical for management and useful for research: an aquatic perspective. Biological Conservation 173: 98-107, $\mathrm{http}: / / \mathrm{dx}$.doi.org/10.1016/j.biocon.2013.07.040

Pyšek P, Richardson DM (2010) Invasive species, environmental change and management, and health. Annual Review of Environment and Resources 35: 25-55

Roy HE, Peyton J, Aldridge DC, Bantock T, Blackburn TM, Britton R, Clark P, Cook E, Dehnen-Schmutz K, Dines T, Dobson M, Edwards F, Harrower C, Harvey MC, Minchin D, Noble DG, Parrott D, Pocock MJO, Preston CD, Roy S, Salisbury A, Schönrogge K, Sewell J, Shaw RH, Stebbing P, Stewart AJA, Walker KJ (2014) Horizon scanning for invasive alien species with the potential to threaten biodiversity in Great Britain. Global Change Biology, http://dx.doi.org/10.1111/gcb.12603

Ruiz G, Fotonoff P, Hines AH (1999) Non-indigenous species as stressors in estuarine and marine communities: Assessing invasion impacts and interactions. Limnology and Oceanography 44(3): 950-972

Sambrook K, Holt RHF, Sharp R, Griffith K, Roche RC, Newstead RG, Wyn G, Jenkins SR (2014) Capacity, capability and cross-border challenges associated with marine eradication programmes in Europe: The attempted eradication of an invasive non-native ascidian, Didemnum vexillum in Wales, United Kingdom. Marine Policy 48: 5158, http://dx.doi.org/10.1016/j.marpol.2014.03.018

Schuchert P (2010) The European athecate hydroids and their medusae (Hydrozoa, Cnidaria): Capitata Part 2. Revue Suisse de Zoologie 117(3): 337-555

Terlizzi A, Bevilacqua S, Fraschetti S, Boero F (2003) Taxonomic sufficiency and the increasing insufficiency of taxonomic expertise. Marine Pollution Bulletin 46: 556-561, $\mathrm{http}: / / \mathrm{dx}$.doi.org/10.1016/S0025-326X(03)00066-3

Tsiamis K, Montesanto B, Panayotidis P, Katsaros C, Verlaque M (2010) Updated records and range expansion of alien marine macrophytes in Greece (2009). Mediterranean Marine Science 11(1): 61-80, http://dx.doi.org/10.12681/mms.91

Wotton DM, O'Brien C, Stuart MD, Fergus DJ (2004) Eradication success down under: heat treatment of a sunken trawler to kill the invasive seaweed Undaria pinnatifida. Marine Pollution Bulletin 49(9-10): 844-849, $\mathrm{http}: / / \mathrm{dx}$.doi.org/10.1016/j.marpolbul.2004.05.001 